This is a self-archived version of an original article. This version may differ from the original in pagination and typographic details.

Author(s): Komonen, Atte; Müller, Jörg

Title: Dispersal ecology of deadwood organisms and connectivity conservation

Year: 2018

Version: Accepted version (Final draft)

Copyright: (C) 2018 Society for Conservation Biology

Rights: In Copyright

Rights url: http://rightsstatements.org/page//nC/1.0/?language=en

Please cite the original version:

Komonen, A., \& Müller, J. (2018). Dispersal ecology of deadwood organisms and connectivity conservation. Conservation Biology, 32(3), 535-545. https://doi.org/10.1111/cobi.13087 


\title{
Dispersal ecology of deadwood organisms and connectivity conservation
}

\author{
Atte Komonen ${ }^{1} \&$ Jörg Müller ${ }^{2,3}$ \\ ${ }^{1}$ University of Jyväskylä, Department of Biological and Environmental Science, P.O. Box 35, FI-40014 \\ University of Jyväskylä, Finland. \\ ${ }^{2}$ Bavarian Forest National Park, Freyunger Str. 2, D-94481 Grafenau, Germany \\ ${ }^{3}$ Field Station Fabrikschleichach, Department of Animal Ecology and Tropical Biology, Biocenter, \\ University of Würzburg, Glashüttenstraße 5, 96181 Rauhenebrach, Germany
}

Correspondence: atte.komonen@jyu.fi; tel +358-40-8053894

Keywords: dispersal, habitat amount, habitat area, habitat quality, protected area management, saproxylic

Running head: Deadwood organisms

Article Impact Statement: Dispersal ability of saproxylics suggests forest conservation should focus on increasing good quality habitat, rather than connectivity.

\section{Abstract}

Limited dispersal knowledge for most organisms hampers effective connectivity conservation in fragmented landscapes. In forest ecosystems, dead-wood dependent organisms (i.e. saproxylics) suffer from forest management and degradation globally. We review the empirical evidence on dispersal ecology of saproxylic insects and fungi. We focus on direct studies (e.g. mark-recapture, radio telemetry), field experiments and population genetic analyses. Our review revealed two somewhat opposite results: based on direct methods and experiments dispersal is limited within a few kilometers, whereas genetic studies generally find little genetic structure over tens of kilometers, indicating long-distance dispersal. Direct dispersal studies and field experiments, however, suffered from a small study extent and thus could not have detected long-distance dispersal. Particularly for fungi there is obvious need for more studies at management-relevant

This article has been accepted for publication and undergone full peer review but has not been through the copyediting, typesetting, pagination and proofreading process, which may lead to differences between this version and the Version of Record. Please cite this article as doi: 10.1111/cobi.13087.

This article is protected by copyright. All rights reserved. 
scales (1 to $10 \mathrm{~km}$ ). Genetic studies in turn suffered from now outdated markers, small number of loci investigated, and the inherent difficulties in inferring dispersal from genetic population structure. Although there were systematic and species-specific differences in dispersal ability, fungi being better dispersers than insects, it seems that in both groups colonization and establishment, not dispersal per se, are limiting their occurrence at management relevant scales. Because most studies were from forest landscapes in Europe, particularly from the boreal region, more data are needed from non-forested landscapes, in which fragmentation effects are likely to be more pronounced. Given the potential for long-distance dispersal and the logical necessity of habitat area being a more fundamental landscape attribute than the spatial arrangement of habitat patches (i.e. connectivity sensu strict), retaining high quality dead-wood habitat is more important than explicit connectivity conservation in many cases.

\section{Introduction}

Habitat loss and degradation affects species persistence in all ecosystems. Forests are the most diverse terrestrial ecosystem, but are declining in area and quality. In many regions, the proportion of primary or old-growth forest to all forest area has declined below 10\% (Schmitt et al. 2009), and the remaining areas are relatively small and isolated fragments amid managed landscapes. In such landscapes the negative effects of decreased connectivity on species persistence should be more pronounced than in landscapes with more habitat (Rybicki \& Hanski 2013). Furthermore, the ecological quality of protected and managed forests, manifested in high numbers of dead wood and veteran trees, has been deteriorated by forest management (Chaudhary et al. 2016). Due to the loss of area, increased fragmentation and declined quality of old-growth forests, many dead-wood dependent species (i.e. saproxylics) have become threatened (Stokland et al. 2012). Globally, the number of saproxylic species is estimated to range 0.4-1 million, and in the well-studied northern Europe they account for $25 \%$ of all forest species, comprising mostly fungi and invertebrates (Stokland et al. 2012). Ecologically and economically effective connectivity conservation requires dispersal knowledge; unfortunately, dispersal ecology of saproxylics is particularly poorly known and there is no synthesis of the subject matter. 
Dispersal is a fundamental ecological process, which influences distribution of genetic and taxonomic diversity in all ecosystems (Trakhtenbrot et al. 2005). Dispersal can be defined as the movement of organisms, propagules or genes, and it can be quantified as the rate of movement or distance moved (Driscoll et al. 2014). For successful colonization, dispersing individuals and propagules must also remain viable and establish in the new environment. Connectivity describes how well species can move among habitat patches, and it can be measured as dispersal success or search time (Tischendorf \& Fahrig 2000). Because such detailed knowledge on species dispersal behavior is rarely available, connectivity is often measured as landscape structure, preferably within the assumed dispersal distances of target species (Moilanen \& Nieminen 2002; Kindlmann \& Burel 2008). The aim of connectivity conservation is to facilitate dispersal among habitat patches to enhance genetic exchange and recolonization, dampening of population fluctuations, and, ultimately, to maintain viable populations and evolutionary potential (Driscoll et al. 2014).

Considering saproxylics the empirical evidence on their dispersal ability and the importance of connectivity is mainly indirect. It is based on comparisons of species richness or presence-absence in stands with varying spatio-temporal isolation, or in landscapes with varying levels of fragmentation (Sverdrup-Thygeson et al. 2014). If carefully designed, such occupancy studies could provide valuable insights on the importance of dispersal and connectivity, but few studies have been able to disentangle the relative importance of habitat connectivity per se from habitat amount (or dispersal limitation from habitat limitation) at management relevant scales (Fahrig 2013). For saproxylics, these studies have been at a very small, substrate scale (Schiegg 2000a,b), have used vague proxies for dispersal limitation (Janssen et al. 2016), or have been conducted in continuous forest landscapes hampering habitat quantification (Seibold et al. 2017). The other confusing issue is related to the ordinary connectivity measures. They generally incorporate the amount of habitat surrounding the focal patch (Moilanen \& Nieminen 2002) or the total amount of habitat in a landscape (Kindlmann \& Burel 2008). Combining habitat amount and spatial arrangement is ecologically justified but, consequently, studies which have reported significant effects of habitat connectivity (e.g. Laaksonen et al. 2008; Abrego et al. 2015) have in fact not been able disentangled habitat amount and connectivity per se satisfactorily (see Fahrig 2013 for an overview); this is often forgotten in ordinary language and practical management.

Disentangling the relative importance of habitat amount and connectivity is important, because conservation managers must prioritize limited resources among different management actions. The unavoidable result of prioritization is that "...every sensible thing we do is another sensible thing we 
don't" (Gilbert 2011). Stepping stones and corridors, for example, are widely advocated in international and national forest policies, as well as in practical conservation to increase connectivity (Bennett \& Mulongoy 2006; Päivinen et al. 2011; Mergner 2014; U.S. Forest Service 2015); this may limit the use of other tools, which are ecologically more sound, such as setting aside good quality habitat or improving habitat quality by restoration. Without species-specific knowledge on dispersal behavior and ecology, we cannot scale the effect of distance in the ordinary connectivity measures or determine the appropriate scale of management actions (Ranius et al. 2011a), and hence connectivity management is speculative at best.

In this paper, we review the empirical evidence on dispersal ability of saproxylic insects and fungi, focusing on direct studies (flight mills, mark-recapture, radio telemetry), as well as on colonization experiments in the field and population genetic analyses. We discuss challenges in measuring dispersal for saproxylics, practical conservation implications and urge some rethinking in connectivity conservation. Although most studies were on saproxylics in boreal and temperate Europe, we provide some insights concerning other forest organisms and ecosystems.

\section{Methods}

We searched papers focusing on direct studies, field experiments and population genetic analyses using keywords "saproxylic" and "dispersal", and "wood-decaying" and "dispersal" in Web of Science $\left(11^{\text {th }}\right.$ October 2016). The reference lists of all articles were examined for additional studies; only articles in English were included, with one exception. From each paper we extracted information on taxa, geographic area, methodology (telemetry, mark-recapture, genetics, flight mill, field experiment), tree species (conifer or broadleaved), study extent (kilometers, area), dispersal rate (colonization or spore production rate) and maximum dispersal distance (meters). For insects we also extracted information on microhabitat: basidiome, subcortical, wood boring, tree hollow, subterranean. We selected the maximum dispersal distance, because it was available in most studies and the long-distance dispersal ability is critical for population spread and maintenance of genetic diversity. The reviewed literature is not exhaustive for some pest species, but is likely to cover most, if not all, studies on rare and threatened species. Studies which included several methods or species were considered as independent studies, whereas studies which were replicated over years in the same site were not. 
To summarize the results of the dispersal studies, we divided them in five categories: local scale $(<50$ $\mathrm{m}$ ) covers the vicinity of a deadwood object, stand scale (50 to $1000 \mathrm{~m}$ ) corresponds to the common forest management unit in Europe, landscape scale (1 to $10 \mathrm{~km}$ ) covers the typical scale of spatial conservation planning, and regional scale (10 to $500 \mathrm{~km}$ ) covers many states, federal states or respective administrational units. Studies at larger scales $(>500 \mathrm{~km})$ belonged to the continental scale.

\section{Results}

\section{Overview}

Altogether we found 78 papers on dispersal of saproxylic species (Supporting Information). $79 \%$ of the studies was from Europe, $12 \%$ from North America, $6 \%$ from temperate Asia, and $3 \%$ from the tropics. $72 \%$ of the studies was on invertebrates, mostly on Coleoptera, and the rest on fungi. All fungal studies, except one, were from Europe. 55\% of the studied invertebrate species and all the studied rare invertebrates were associated with broadleaved trees. The studies on coniferassociated species were almost exclusively on pests or their predators. $43 \%$ of the studies focused on subcortical species, $20 \%$ on fungivores, $16 \%$ on wood borers and $16 \%$ on tree-hollow-dwelling species. Fungal studies were mainly (77\%) on spruce-associated species.

Altogether 27 invertebrate and 18 fungal species had been studied (excluding studies on the entire community). In insects, there were more studies on common $(n=10)$ than on rare species $(n=7)$, the latter being the beetles Oplocephala haemorrhoidalis, Osmoderma eremita/barnabita (the latter is recently split from O. eremita), Lucanus cervus, Rosalia alpina, Elater ferrugineus, the fly Hammerschmidtia ferruginea and the pseudoscorpion Larca lata. In fungi, ten common and eight rare species had been studied, the latter focusing on Fomitopsis rosea and Phlebia centrifuga.

Mark-recapture $(n=25)$ and genetics $(n=12)$ were the most common methods in studies of invertebrates and fungi, respectively. Field experiments and population genetic studies of insects and fungi covered all the five spatial scales, but only few studies were available at the continental scale for insects or at the landscape scale for fungi (Fig. 1; Supporting Information).

Insects

This article is protected by copyright. All rights reserved. 
Mark-recapture studies (MRR; $n=25$ studies, 15 species) generally had a limited spatial extent (med $=1000 \mathrm{~m}, \max =7000 \mathrm{~m}, \mathrm{n}=16$; or $\operatorname{med}=1 \mathrm{ha}, \max =40 \mathrm{ha}, \mathrm{n}=10$; one study included two species, hence $n=26$ ). Based on the MRR studies $10-89 \%$ of the individuals dispersed from the release site. The median of the maximum dispersal distances was $1000 \mathrm{~m}(\min =59, \max =5300 \mathrm{~m} ; \mathrm{n}=25$; Fig. 2). One of the longest dispersal distances $(4-5 \mathrm{~km})$ was documented for a rare aspen-associated syrphid fly (Rotheray et al. 2014). Different methods gave rather similar dispersal distances for the rare hermit beetle (Osmoderma spp.) (Fig. 3), but the dispersal rates and distances seemed to be smaller for the Swedish populations than for the more southern European populations.

In the radio telemetry studies ( $n=5$ studies, 3 species), $12-75 \%$ of the individuals dispersed from the release site. The study extent or search area radius ranged from $500 \mathrm{~m}$ to $2 \mathrm{~km}$, and the dispersal distances from $180 \mathrm{~m}$ to $2065 \mathrm{~m}$; half of the studies documented dispersal over $1 \mathrm{~km}$. Most telemetry studies were on 0 . eremita $(n=4)$. Again, the shortest observed distances were for Swedish populations $(\max =330 \mathrm{~m}$, mean $=82 \mathrm{~m})$, whereas in Italy $39 \%$ dispersed further than 250 $\mathrm{m}(\mathrm{max}=1504 \mathrm{~m})$ and in France the maximum distance was $700 \mathrm{~m}$.

Flight mill studies ( $\mathrm{n}=10$ studies, 11 species) indicated very high dispersal potential, measured as either flight time or distance. The average of the maximum flight distances was $53 \mathrm{~km}(n=6)$. The record distance of $125 \mathrm{~km}$ was documented for the beetle Bolitophagus reticulatus; a rare closelyrelated O. haemorrhoidalis dispersed $29 \mathrm{~km}$ (Jonsson 2003). Continuous flight for hours was regularly observed.

Field experiments ( $\mathrm{n}=10$ studies, 61 species) evaluated dispersal distances by placing traps at different distances from source populations or at different landscapes in terms of habitat availability. Most field experiments were conducted at the local to landscape scale (Supporting Information). The maximum trapping distance from source populations was typically less than $3 \mathrm{~km}$ and many invertebrate species successfully colonized over $1 \mathrm{~km}$. In one study, many pest beetle species were observed 10-171 km from the suspected sources (Nilssen 1984). The studies which documented dispersal limitation at the scale of 1 to $10 \mathrm{~km}$ were multispecies studies, and there was always some species which were able to disperse the maximum study distance.

Genetic differentiation of populations was reported in 7 studies and 10 species. Generally, there was little genetic differentiation over 100s of $\mathrm{km}$ (Supporting Information). Interestingly, two flightless pseudoscorpions living in tree hollows revealed very little genetic differentiation up to $500 \mathrm{~km}$ 
(Ranius \& Douwes 2002). Genetic differentiation of the threatened R. alpina was very low among populations up to $600 \mathrm{~km}$ (Drag et al. 2015). Populations of O. barnabita had positive kinship up to $10 \mathrm{~km}$, indicating dispersal limitation at this scale, but the estimated average dispersal distance was an order of magnitude larger than that reported for Osmoderma spp. by other methods (Oleksa et al. 2013). For beetles living in fungal basidiomes, all studies (except one) revealed a lack of genetic differentiation over tens or hundreds of kilometers. Genetic studies used amplified fragment length polymorphism (AFLP), random amplification of polymorphic DNA (RAPD) and protein markers. The average number of loci examined was 43 , but the range was considerable (3-105).

Fungi

Field experiments ( $\mathrm{n}=10$ studies, 12 species; 1 study examined the entire community) evaluated dispersal distances by placing traps at different distances from source populations or at different landscapes in terms of habitat availability. Field experiments were conducted at all spatial scales (Supporting Information). The maximum distance traps were placed from the source populations was typically $1 \mathrm{~km}$. In all studies, spores were trapped from the maximum distance studied, even from a remote oceanic island at least $50 \mathrm{~km}$ from the nearest potential source (Kallio 1970), or from an urban rooftop over $1000 \mathrm{~km}$ from the potential source (Hallenberg \& Küffer 2001). The spore deposition rates varied greatly within species, and ranged from tens to hundreds of thousands of spores $\mathrm{cm}^{-2} \mathrm{~h}^{-1}$ for common and rare species (Möykkynen et al. 1997; Norros et al. 2012). The background deposition rates for rare species in forest landscapes ranged from a few to hundreds of spores $\mathrm{m}^{-2} \mathrm{~d}^{-1}$ (Edman et al. 2004a,b,c). In some cases, these background levels were reached already $<100 \mathrm{~m}$ from the source (Norros et al. 2012).

Genetic differentiation of populations was reported in 12 studies and 9 species. Similar to field experiments, all scales had been studied, although there was only one study at the scale of 1 to 10 kilometers (Supporting Information). The observed genetic differentiation was mainly on the larger scales (Fig. 1). Considering the old-growth forest specialists F. rosea, P. centrifuga and Phellinus nigrolimitatus, there was very little or no genetic differentiation and isolation-by-distance over 100s of kilometers. Phlebia centrifuga, for example, showed very little to moderate genetic differentiation and no clear isolation-by-distance for the majority of populations across Fennoscandia, although the most isolated population showed the highest differentiation from the other populations. Genetic studies used arbitrary primed PCR, restriction length polymorphism (RFLP), inter simple sequence 
repeat (ISSR), allele-specific amplification (ASA), RAPD and AFLP. These studies typically included only about 10 loci (but see Parrent et al. 2004).

\section{Discussion}

Insects

Direct methods indicated that the dispersal of saproxylic insects is limited within a few kilometers from source populations. Although MRR and telemetry are suitable for measuring movement in nature, they regularly miss the important long-distance dispersal. Furthermore, the direct dispersal studies suffered from a small study extent and thus could not have detected long-distance dispersal. Realistic estimates of dispersal distance in mark-recapture studies, even for small insects, may require a study area of at least $50 \mathrm{~km}^{2}$ and over 500 recaptured individuals (Franzén \& Nilsson 2007). Only one third of the reviewed studies included over 500 recaptured individuals, and, with one exception, none covered a distance over $2 \mathrm{~km}$. There were several more or less anecdotal reports on dispersal distances, which were way beyond the distances observed in direct studies (4-14 km; Fielding et al. 1991; Hanks et al. 1998; Etxebeste et al. 2016). Flight mill studies further indicated that dispersal ability per se might not be a limiting factor. Although flight mills are unnatural and may over- or underestimate dispersal ability (Riley et al. 1997), they may reveal physiological limitations to flying and can be used to compare flight abilities of different species, sexes and ages in a standardized way (Jonsson 2003).

Field experiments in which substrate baits or traps were placed at different distances from the known or suspected source populations revealed a high variability in maximum dispersal distances, from tens of meters to $171 \mathrm{~km}$. Nevertheless, the target species (or some of them in multispecies studies) colonized the maximum distance in all studies. Field experiments can also be used to measure colonization, not only dispersal. For example, some studies documented larvae galleries and exit holes, which indicate successful colonization (Nuorteva \& Nuorteva 1968; Nilssen 1984; Ranius et al. 2011b). The drawback of field experiments is that the origin of the colonizers remains uncertain, unless combined with marking of individuals (see Rotheray et al. 2014). Most of the experimental studies, however, could not fully exclude the possibility of other than the assumed sources for individuals. Nevertheless, field experiments in which logs are placed in treeless tundra or islets is as good as it can get. 
Population genetic studies on insects revealed genetic differentiation, as well as isolation-bydistance, among the studied populations; however, there was less evidence for genetic differentiation at the scale of 1000 s of meters, whereas more so at larger scales. Genetic differentiation among populations, however, provide only indirect evidence about contemporary dispersal, as it reflects also historic dispersal rates, bottlenecks and extinction-colonization dynamics (Driscoll et al. 2014). Genetic studies on saproxylic insects are more recent than on fungi. This is reflected in that only one study used the now outdated RAPD/ISSR markers (Rabouam et al. 1999), as well as in the larger number of loci investigated, which is crucial in quantifying population genetic structure reliably. There are also new statistical approaches in inferring dispersal from genetic data (Driscoll et al. 2014; see Oleksa et al. 2013 and Drag et al. 2015 for examples on saproxylics). Despite these advances, genetic analyses may best be applied in combination with other methods.

There is evidence for systematic differences in species dispersal ability among ecological groups. Pioneer species, such as many bark beetles and cerambycids, are subcortical and wood-boring and seem to have better dispersal ability than the species in tree hollows or in wood at advanced decayed stages. Some flightless saproxylics, however, appear to be efficient dispersers due to their hitch-hiking strategy (Ranius \& Douwes 2002). The good dispersal ability of pioneer species is biologically plausible, since the first decay stages are shorter in duration than the later decay stages, which could have selected for better dispersal ability (Stokland et al. 2012). The observed longdistance dispersal of many pioneer pest species should be generalized with caution to rare species (Ranius 2006). Nevertheless, reviewed flight mill studies and some of the genetic studies did not indicate consistent differences between pests and other saproxylics. The apparent superior dispersal ability of some pest species might be partly explained by the fact that the number of long-distance dispersers depends positively on population size, which for pests is enormous during outbreaks. Finally, pheromone traps have been extensively used to study pest species, which makes longdistance trapping more effective. Pheromone trapping of rare saproxylics is just taking its first steps (Larsson \& Svensson 2011; Svensson et al. 2011)

Fungi

Experimental studies on spore deposition of wood-decaying fungi show that fungi produce enormous amounts of spores. Although most spores land near the source basidiome (Edman et al. 2004a; Norros et al. 2012), viable spores can travel hundreds of kilometers (Kallio 1970; Hallenberg \& Küffer 2001). Yet, there is high interspecific variability in spore dispersal, which might be partly 
explained by species' traits (e.g. spore size and shape); species traits could also explain interspecific differences in colonization and establishment (Kauserud et al. 2008), but studies are few (Nordén et al. 2013; Norros et al. 2014). Considering fungi as a whole, many species can disperse kilometers (Peay et al. 2012), and potential for inter-continental dispersal seems not to be an exception (Brown \& Hovmøller 2002; Geml et al. 2012). Similarly, red-listed epiphytic lichens have been shown to disperse over several kilometers, establishment being the limiting factor for the colonization of new sites in forest landscapes (Gjerde et al. 2014) or new trees in old-growth forest landscapes (Ronnås et al. 2017).

The reviewed experimental studies do have some shared methodological issues, which might have underestimated dispersal distances. The spore-trapping distances in most experiments were less than $1 \mathrm{~km}$, which made it impossible to detect long-distance dispersal. Furthermore, traps (petri dishes) were exposed to spore rain only for few hours. Yet, the $5 \%$ colonization rates at the maximum distances are relatively high (e.g. Norros et al. 2012), and a downed log with more than 100 s to 1000 s times larger area has much higher colonization probability over time even at large distances. Overestimating dispersal distances is also possible. There is always uncertainty in identifying the true source of the trapped spores, because of the imperfect distributional knowledge of fungi (Lõhmus 2009). In general, the scale and importance of dispersal limitation for cryptic organisms, such as fungi, has become a major point of debate (Peay et al. 2012).

To derive true dispersal distances from the spore trapping experiments is not simple. The often assumed monotonous distance-decay model may not adequately describe long-distance dispersal of airborne propagules (Kuparinen 2006; Dam 2013). Wind can transport spores in groups inside discrete air packages over considerable distances (Norros et al. 2012) and wind conditions, such as turbulences, further elongate dispersal distances (Nathan \& Katul 2005). For example, the abundance-based species composition, determined by DNA methods, of wood-decaying fungi in the spore cloud was similar in a 4-ha old-growth forest and in the surrounding managed forest landscape in Finland up to $20 \mathrm{~km}$ (Panu Halme, pers. comm.). The lack of distance effect may result from spores building up from many sources, and especially the large "mainland" populations may be more important sources of spores than the smaller nearby populations, as suggested for bryophytes and lichens (Hylander 2009; Sundberg 2013; Gjerde et al. 2014). Because airborne spores may lose viability due to UV radiation (Norros et al. 2015), the spore-cloud composition may give a misleading view about the potential for successful colonization and establishment. However, most spores are 
released at night (Kramer 1982; Gilbert 2005) and the nights are long in the northern autumn, which is the main spore production period at least for annual species (Nuss 1986).

Population genetic studies on fungi do not generally support dispersal limitation from the local to landscape scales. Beyond the $10 \mathrm{~km}$ scale the results area mixed: there is very little evidence of dispersal limitation for abundant generalist species, while some for rare specialists. For the rare species there are indications of genetic differentiation across Fennoscandia (>500 km), but the results about the isolation-by-distance are more ambiguous (Högberg \& Stenlid 1999; Franzén et al. 2007). For some rare species the entire Fennoscandia has been suggested to form a single mating population (Kauserud \& Schumacher 2002, 2003). The lack of genetic differentiation has also been interpreted to indicate time lag in the population response to past forest degradation (Franzén et al. 2007). Time lag, however, is a problematic concept scientifically, because a lack of effect can always be explained as a time lag. The ambiguous results may also result from the use of now outdated RAPD/ISSR markers (Rabouam et al. 1999) and small number of loci investigated. Indeed, the only study which examined a reasonable number of loci was done in the tropics (Parrent et al. 2004). The study found out that a significant amount of total genetic variation was partitioned among populations separated by $10 \mathrm{~s}$ to $100 \mathrm{~s}$ of $\mathrm{km}$.

Real world documentation of colonization is rare for saproxylics. In one example the fungus Antrodiella citrinella had survived as a relict in two old-growth forest remnants in the Bohemian Forest. After a bark-beetle created high amounts of substrate over thousands of hectares, the fungus colonized new areas over 30km from the remnants within a decade (Bässler \& Müller 2010). The other example is from a national park in Finland. Two 1-ha fragments, which had been managed previously, were burned as a restoration measure. As a result, the species richness and abundance of red-listed fungi increased beyond the pre-fire situation (Penttilä et al. 2013). In both examples, there are two possible explanations for the observed increases: either the individuals were already present as mycelia prior to the disturbances, which then promoted fruiting, or the species colonized after the disturbances. In both cases, however, substrate amount and quality, not restricted dispersal, was the limiting factor. In heavily-managed or non-forested landscapes, however, a lack of source populations within 100s of kms might be resolved only by reintroduction of threatened beetles and fungi (Drag \& Cizek 2015; Abrego et al. 2016). 
The dispersal literature of saproxylics is not extensive but it is growing: $58 \%$ of the reviewed studies were from the $21^{\text {st }}$ century; yet, there are significant knowledge gaps considering different spatial scales, as well as in geographical and taxonomic coverage. More targeted research is clearly needed at management relevant scales, i.e. from kilometers to tens of kilometers. This is particularly true for fungi, but also most insect studies at the management relevant scales were conducted at the shorter end of the scale below $2 \mathrm{~km}$. Most studies were from forest landscapes, so more data are needed from non-forested landscapes, in which fragmentation effects maybe more pronounced (see Rybicki \& Hanski 2013). Globally, such landscapes are common in many temperate and tropical areas.

Tropical areas are particularly poorly represented among the studies on saproxylics (but see Parrent et al. 2004; Galindo-Cardona et al. 2007; Seibold et al. 2015), and more studies are urgently needed to aid conservation planning and decision making. Several factors hamper the transferability of the knowledge from northern latitudes to tropics. In tropics, tree decay is faster, which might have selected for good dispersal ability. Very high tree species diversity, on the other hand, might have promoted generalization and thus poor dispersal. Indeed, tropical fungi seem to be generalists in terms of host tree species (Gibertoni et al. 2015), but not necessarily in terms of dead wood types (Urcelay \& Robledo 2004). Wind conditions in dense tropical forests are likely to be very different from the more open boreal and temperate forests, which might hinder dispersal of airborne spores (see Gilbert 2005).

Our take home messages for researchers are that to disentangle the relative importance of habitat amount, quality and connectivity we clearly need more carefully designed occupancy studies with sufficient extent (see Fahrig 2013); to better understand the mechanisms behind dispersal we need well-designed direct dispersal studies, preferably with several methods that can capture longdistance dispersal (see Drag et al. 2011, 2015); to understand intraspecific variation in dispersal behavior and the influence of landscape on dispersal behavior, we need to study dispersal in different regions and years (see Svensson et al. 2011; Chiari et al. 2013); to understand dispersal fully, we need to study establishment, not only movement (see Norros et al. 2015). Finally, because of the small study extents and sample sizes, as well as inherent difficulties in detecting dispersal over long distances, long-distance dispersal should not be automatically explained away as something exceptional. 


\section{Management implications}

Despite the above-mentioned knowledge gaps, some management implications are apparent. The review suggests that although the dispersal ability per se up to a landscape scale might not be a limiting factor for most saproxylic insects, and fungi in particular, colonization and establishment might be. Because colonization and establishment are linked to habitat amount and quality, the fundamental question in conservation is not if connectivity sensu strict is important, but its relative importance in relation to habitat amount and quality. Managers and scientists must recognize those situations in which connectivity deserves particular attention (Fahrig 2013). Connectivity could be important if there is a high probability of local extinction due to demographic or environmental stochasticity (e.g. in small woodland key habitats; Nordén et al. 2013). However, saproxylic populations in most protected area networks are not characterized by dynamic equilibrium of colonizations and extinctions in ecological time scales; for example, many saproxylic beetles (Horion 1953; Brechtel \& Kostenbader 2002; Buse 2012; Soldati et al. 2015) and fungi (Bässler \& Müller 2010; Penttilä et al. 2006) have persisted for decades or centuries in reserves and in isolated fragments.

Even if demographic and environmental stochasticity were important, the best way to counteract their adverse effects would be to establish large and good quality conservation areas, or to improve habitat quality by restoration and management. As already mentioned, such large and good quality reserves may enhance long-distance dispersal more than the nearby fragments, as shown for winddispersed tree epiphytes (Hylander 2009; Sundberg 2013; Gjerde et al. 2014). Epiphytes share similar sexual (ascospore and gamete) dispersal ecology with saproxylic fungi, so a lot can be learned from these studies. Because epiphytes typically occupy living and moribund veteran trees, they are negatively affected by forest management; hence, our general management implications for fungi may apply to these species as well. Large reserves would also maintain genetic diversity; however, connectivity is rarely an issue in conservation of genetic diversity, because very little long-distance dispersal is adequate to maintain genetic heterogeneity (Trakhtenbrot et al. 2005). Finally, due to the restricted distribution of many tropical species (for saproxylics see Araujo et al. 2015; Gibertoni et al. 2015), connectivity of conservation areas might be less important for saproxylic species in the tropics than in the more homogeneous boreal and temperate regions.

Our motivation for this review was that there was no summary of the dispersal ability of saproxylic species, despite dispersal's pivotal role in practical connectivity conservation. Our review revealed

This article is protected by copyright. All rights reserved. 
that the evidence on dispersal is limited in many ways and there are several sources of error in documenting long-distance dispersal. Our review suggests, together with the recent evidence from other rare forest-dwelling taxa (Gjerde et al. 2014; Ronnås et al. 2017), that long-distance dispersal deserves a closer scrutiny. The potentially underestimated dispersal ability of saproxylics may lead into adverse management decisions, if habitat amount and quality are sacrificed for spatial arrangement of reserves, stepping stones and corridors. Indeed, there is little empirical evidence that the spatial arrangement of habitat would have significant effects on landscape level persistence of any species (Fahrig 2013). Habitat amount and quality are also more certain to increase population sizes and numbers of dispersers than are increases in aggregation (Hodgson et al. 2009). Because the total habitat amount and mean connectivity (however defined) in a landscape are interwoven, increasing amount almost invariably increases also connectivity. Our view is that conservation managers should focus on retaining, creating and maintaining high quality habitat, not only in conservation of saproxylics but also in other species groups and ecosystems.

\section{Acknowledgments}

We thank H.-J. Poethke, L. Cizek, L. Drag, C. Bouget, J. Kotiaho, M. Puurtinen, C. Bässler, P. Halme, J. Toikkanen and anonymous referees for comments on the manuscript, and I. Puumala, P. Halme and P. Martikainen for sharing unpublished data.

\section{Supporting Information}

List of the reviewed studies (Appendix S1), their summaries (Appendix S2) and the data for Figure 3 (Appendix S3) are available online. The authors are solely responsible for the content and functionality of these materials. Queries (other than absence of the material) should be directed to the corresponding author.

\section{Literature Cited}

Abrego N, Bässler C, Christensen M, Heilmann-Clausen J. 2015. Implications of reserve size and forest connectivity for the conservation of wood-inhabiting fungi in Europe. Biological Conservation 191:469-477. 
Abrego N, Oivanen P, Viner I, Nordén J, Penttilä R, Dahlberg A, Heilmann-Clausen J, Somervuo P, Ovaskainen O, Schigel D. 2016. Reintroduction of threatened fungal species via inoculation. Biological Conservation 203:120-124.

Araujo LS, Komonen A, Lopes-Andrade C. 2015. Influences of landscape structure on diversity of beetles associated with bracket fungi in Brazilian Atlantic Forest. Biological Conservation 191:659666.

Bennett G, Mulongoy KJ. 2006. Review of Experience with Ecological Networks, Corridors and Buffer Zones. Secretariat of the Convention on Biological Diversity, Montreal, Technical Series No. 23. Available from http:www.syzygy.nl/publications_bc.php (accessed 27 March 2017).

Brechtel F, Kostenbader H. 2002. Die Pracht- und Hirschkäfer Baden-Württembergs. Ulmer, Stuttgart.

Brown JKM, Hovmøller MS. 2002. Aerial dispersal of pathogens on the global and continental scales and its impact on plant disease. Science 297:537-541.

Buse J. 2012. Ghosts of the past: flightless saproxylic weevils (Coleoptera: Curculionidae) are relict species in ancient woodlands. Journal of Insect Conservation 16:93-102.

Bässler C, Müller J. 2010. Importance of natural disturbance for recovery of the rare polypore Antrodiella citrinella Niemelä \& Ryvarden. Fungal Biology 114:129-133.

Chaudhary A, Burivalova Z, Koh LP, Hellweg S. 2016. Impact of forest management on species richness: global meta-analysis and economic trade-offs. Scientific Reports 6:23954:1-10.

Chiari S, Carpaneto GM, Zauli A, Zirpoli GM, Audisio P, Ranius T. 2013. Dispersal patterns of a saproxylic beetle, Osmoderma eremita, in Mediterranean woodlands. Insect Conservation and Diversity 6:309-318.

Dam N. 2013. Spores do travel. Mycologia 105:1618-1622.

Drag L, Hauck D, Pokluda P, Zimmermann K, Cizek L. 2011. Demography and dispersal ability of a 
threatened saproxylic beetle: A mark-recapture study of the Rosalia longicorn (Rosalia alpina). PLOS ONE (e21345) DOI: 10.1371/journal.pone.0021345

Drag L, Cizek L. 2015. Successful reintroduction of an endangered veteran tree specialist: conservation and genetics of the Great Capricorn beetle (Cerambyx cerdo). Conservation Genetics $16: 267-276$.

Drag L, Hauck D, Berces S, Michalcewicz J, Jelaska LS, Aurenhammer S, Cizek L. 2015. Genetic differentiation of populations of the threatened saproxylic beetle Rosalia longicorn, Rosalia alpina (Coleoptera: Cerambycidae) in Central and South-east Europe. Biological Journal of the Linnean Society 116:911-925.

Driscoll DA, et al. 2014. The trajectory of dispersal research in conservation biology. Systematic review. PLOS ONE (e95053) DOI: 10.1371/journal.pone.0095053.

Edman M, Kruys N, Jonsson BG. 2004a. Local dispersal sources strongly affect colonization patterns of wood-decaying fungi on spruce logs. Ecological Applications 14:893-901.

Edman M, Gustafsson M, Stenlid J, Jonsson BG, Ericson L. 2004b. Spore deposition of wood-decaying fungi: importance of landscape composition. Ecography 27:103-111.

Edman M, Gustafsson M, Stenlid J, Ericson L. 2004c. Abundance and viability of fungal spores along a forestry gradient - responses to habitat loss and isolation? Oikos 104:35-42.

Etxebeste I, Sanchez-Husillos E, Alvarez G, Gisbert HMI, Pajares J. 2016. Dispersal of Monochamus galloprovincialis (Col.: Cerambycidae) as recorded by mark-release-recapture using pheromone traps. Journal of Applied Entomology 140:485-499.

Fahrig L. 2013. Rethinking patch size and isolation effects: the habitat amount hypothesis. Journal of Biogeography 40:1649-1663.

Fielding N, Okeefe T, King C. 1991. Dispersal and host-finding capability of the predatory beetle Rhizophagus grandis Gyll. (Col. Rhizophagidae). Journal of Applied Entomology 112:89-98. 
Franzén M, Nilsson SG. 2007. What is the required minimum landscape size for dispersal studies? Journal of Animal Ecology 76:1224-1230.

Franzén I, Vasaitis R, Penttilä R, Stenlid J. 2007. Population genetics of the wood-decay fungus Phlebia centrifuga P. Karst. in fragmented and continuous habitats. Molecular Ecology 16:33263333.

Galindo-Cardona A, Giray T, Sabat AM, Reyes-Castillo P. 2007. Bess beetle (Coleoptera: Passalidae): substrate availability, dispersal, and distribution in a subtropical wet forest. Annals of the Entomological Society of America 100:711-720.

Geml J, Timling I, Robinson CH, Lennon N, Nusbaum HC, Brochmann C, Noordeloos ME, Taylor DL. 2012. An arctic community of symbiotic fungi assembled by long-distance dispersers: phylogenetic diversity of ectomycorrhizal basidiomycetes in Svalbard based on soil and sporocarp DNA. Journal of Biogeography 39:74-88

Gibertoni TB, Nogueira-Melo GS, de Lira CRS, Baltazar JM, Santos PJP. 2015. Distribution of poroid fungi (Basidiomycota) in the Atlantic Rain Forest in Northeast Brazil: implications for conservation. Biodiversity and Conservation 24:2227-2237.

Gilbert D. 2011. Buried by bad decisions. Nature 474:275-277.

Gilbert GS. 2005. Nocturnal fungi: airborne spores in the canopy and understory of a tropical rain forest. Biotropica 37:462-464.

Gjerde I, Blom HH, Heegaard E, Sætersdal M. 2015. Lichen colonization patterns show minor effects of dispersal distance at landscape scale. Ecography 38:939-948.

Hallenberg N, Küffer N. 2001. Long-distance dispersal in wood-inhabiting basidiomycetes. Nordic Journal of Botany 21:431-436.

Hanks LM, Millar JG, Paine TD. 1998. Dispersal of the eucalyptus longhorned borer (Coleoptera : Cerambycidae) in urban landscapes. Environmental Entomology 27:1418-1424. 
Hodgson JA, Thomas CD, Wintle BA, Moilanen A. 2009. Climate change, connectivity and conservation decision making: back to basics. Journal of Applied Ecology 46:964-969.

Horion A. 1953. Faunistik der mitteleuropäischen Käfer, Bd. III, Malacodermata, Sternoxia (Elateridae - Throscidae), München.

Hylander K. 2009. No increase in colonization rate of boreal bryophytes close to propagule sources. Ecology 90:160-169.

Högberg N, Stenlid J. 1999. Population genetics of Fomitopsis rosea - a wood-decay fungus of the old-growth European taiga. Molecular Ecology 8:703-710.

Janssen P, Cateau E, Fuhr M, Nusillard B, Brustel H, Bouget C. 2016. Are biodiversity patterns of saproxylic beetles shaped by habitat limitation or dispersal limitation? A case study in unfragmented montane forests. Biodiversity and Conservation 25:1167-1185.

Jonsson M. 2003. Colonisation ability of the threatened tenebrionid beetle Oplocephala haemorrhoidalis and its common relative Bolitophagus reticulatus. Ecological Entomology 28:159167.

Kallio T. 1970. Aerial distribution of the root fungus Fomes annosus in Finland. Acta Forestalia Fennica 107:1-55.

Kauserud H, Schumacher T. 2002. Population structure of the endangered wood decay fungus Phellinus nigrolimitatus (Basidiomycota). Canadian Journal of Botany 80:597-606.

Kauserud H, Schumacher T. 2003. Genetic structure of Fennoscandian populations of the threatened wood-decaying fungus Fomitopsis rosea (Basidiomycota). Mycological Research 107:155-163.

Kauserud H, Colman JE, Ryvarden L. 2008. Relationship between basidiospore size, shape and life history characteristics: a comparison of polypores. Fungal Ecology 1:19-23.

Kindlmann P, Burel F. 2008. Connectivity measures: a review. Landscape Ecology 23:879-890.

This article is protected by copyright. All rights reserved. 
Kramer CL. 1982. Production, release and dispersal of basidiospores. Pages 33-49 in Frankland J, Hedger JN, Swift MJ, editors. Decomposer basidiomycetes: their biology and ecology. Cambridge University Press, Cambridge.

Kuparinen A. 2006. Mechanistic models for wind dispersal. Trends in Plant Science 11:296-301.

Laaksonen M, Peuhu E, Várkonyi G, Siitonen J. 2008. Effects of habitat quality and landscape structure on saproxylic species dwelling in boreal spruce-swamp forests. Oikos 117:1098-1110.

Larsson M, Svensson G. 2011. Monitoring spatiotemporal variation in abundance and dispersal by a pheromone-kairomone system in the threatened saproxylic beetles Osmoderma eremita and Elater ferrugineus. Journal of Insect Conservation 15:891-902.

Lõhmus A. 2009. Factors of species-specific detectability in conservation assessments of poorly studied taxa: The case of polypore fungi. Biological Conservation 142:2792-2796.

Mergner U. 2014. Ein Plädoyer für die kleinflächige Stilllegung in Wäldern - Small is beautiful. AFZWald 3:25-27.

Moilanen A, Nieminen M. 2002. Simple connectivity measures in spatial ecology. Ecology 83:11311145.

Möykkynen T, Von Weissenberg K, Pappinen A. 1997. Estimation of dispersal gradients of S- and Ptype basidiospores of Heterobasidion annosum. European Journal of Forest Pathology 17:291-300.

Nathan R, Katul GG. 2005. Foliage shedding in deciduous forests lifts up long-distance seed dispersal by wind. Proceedings of the National Academy of Sciences 102:8251-8256.

Nilssen AC. 1984. Long-range aerial dispersal of bark beetles and bark weevils (Coleoptera, Scolytidae and Curculionidae) in northern Finland. Annales Entomologici Fennici 50:37-42.

Nordén J, Penttilä R, Siitonen J, Tomppo E, Ovaskainen O. 2013. Specialist species of wood-inhabiting fungi struggle while generalists thrive in fragmented boreal forests. Journal of Ecology 101:701-712.

This article is protected by copyright. All rights reserved. 
Norros V, Penttilä R, Suominen M, Ovaskainen O. 2012. Dispersal may limit the occurrence of specialist wood decay fungi already at small spatial scales. Oikos 121:961-974.

Norros V, Rannik Ü, Hussein T, Petäjä T, Vesala T, Ovaskainen O. 2014. Do small spores disperse further than large spores? Ecology 95:1612-1621.

Norros V, Karhu E, Nordén J, Vähätalo A, Ovaskainen O. 2015. Spore sensitivity to sunlight and freezing can restrict dispersal in wood-decay fungi. Ecology and Evolution 5:3312-3326.

Nuorteva M, Nuorteva P. 1968. The infestation of timber by bark beetles (Col., Scolytidae) and their enemies in different zones of the Finnish southwestern archipelago. Annales Entomologici Fennici 34:56-65.

Nuss, I. 1986. Ecology of polypores II. The morphological development of polypore fruit bodies and the influence of climate and other factors. Bibliotheca Mycologica 105. J. Cramer, Berlin. (In German)

Oleksa A. 2014. Weak isolation by distance in Diaperis boleti, a fungivorous saproxylic beetle. Journal of Insect Science 14(109). DOI: dx.doi.org/10.1093/jis/14.1.109.

Oleksa A, Chybicki IJ, Gawronski R, Svensson GP, Burczyk J. 2013. Isolation by distance in saproxylic beetles may increase with niche specialization. Journal of Insect Conservation 17:219-233.

Oleksa A, Chybicki IJ, Larsson MC, Svensson GP, Gawronski R. 2015. Rural avenues as dispersal corridors for the vulnerable saproxylic beetle Elater ferrugineus in a fragmented agricultural landscape. Journal of Insect Conservation 19:567-580.

Parrent JL, Garbelotto M, Gilbert GS. 2004. Population genetic structure of the polypore Datronia caperata in fragmented mangrove forests. Mycological Research 108:403-410.

Peay KG, Schubert MG, Nguyen NH, Bruns TD. 2012. Measuring ectomycorrhizal fungal dispersal: macroecological patterns driven by microscopic propagules. Molecular Ecology 21:4122-4136. 
Penttilä R, Lindgren M, Miettinen O, Rita H, Hanski I. 2006. Consequences of forest fragmentation for polyporous fungi at two spatial scales. Oikos 114:225-240.

Penttilä R, Junninen K, Punttila P, Siitonen J. 2013. Effects of forest restoration by fire on polypores depend strongly on time since disturbance - A case study from Finland based on a 23-year monitoring period. Forest Ecology \& Management 310:508-516.

Päivinen J, Björkqvist N, Karvonen L, Kaukonen M, Korhonen KM, Kuokkanen P, Lehtonen H, Tolonen A. 2011. Metsähallituksen metsätalouden ympäristöopas. Metsähallituksen metsätalouden julkaisuja 67. $162 \mathrm{~s}$.

Rabouam C, Comes AM, Bretagnolle V, Humbert J-F, Periquet G, Bigot Y. 1999. Features of DNA fragments obtained by random amplified polymorphic DNA (RAPD) assays. Molecular Ecology 8:493503.

Ranius T. 2006. Measuring the dispersal of saproxylic insects: a key characteristic for their conservation. Population Ecology 48:177-188.

Ranius T, Douwes P. 2002. Genetic structure of two pseudoscorpion species living in tree hollows in Sweden. Animal Biodiversity and Conservation 25:67-74.

Ranius T, Johansson V, Fahrig L. 2011a. Predicting spatial occurrence of beetles and pseudoscorpions in hollow oaks in southeastern Sweden. Biodiversity and Conservation 20:2027-2040.

Ranius T, Martikainen P, Kouki J. 2011b. Colonisation of ephemeral forest habitats by specialised species: beetles and bugs associated with recently dead aspen wood. Biodiversity and Conservation 20:2903-2915.

Riley JR, Downham MCA, Cooter RJ. 1997. Comparison of the performance of Cicadulina leafhoppers on flight mills with that to be expected in free flight. Entomologia Experimentalis et Applicata 83:317-322.

Ronnås C, Werth S, Ovaskainen O, Várkonyi G, Scheidegger C, Snäll T. 2017. Discovery of longdistance gamete dispersal in a lichen-forming ascomycete. New Phytologist 216:216-226.

This article is protected by copyright. All rights reserved. 
Rotheray EL, Bussiere LF, Moore P, Bergstrom L, Goulson D. 2014. Mark recapture estimates of dispersal ability and observations on the territorial behaviour of the rare hoverfly, Hammerschmidtia ferruginea (Diptera, Syrphidae). Journal of Insect Conservation 18:179-188.

Rybicki J, Hanski I. 2013. Species-area relationships and extinctions caused by habitat loss and fragmentation. Ecology Letters 16:27-38.

Schiegg K. 2000a. Are there saproxylic beetle species characteristic of high dead wood connectivity. Ecography 23:579-587.

Schiegg K. 2000b. Effects of dead wood volume and connectivity on saproxylic insect species diversity. Ecoscience 7:290-298.

Schmitt CB, et al. 2009. Global analysis of the protection status of the world's forests. Biological Conservation 142:2122-2130.

Seibold S, Bässler C, Brandl B, Gossner MM, Thorn S, Ulyshen MD, Müller J. 2015. Experimental studies of dead-wood biodiversity - A review identifying global gaps in knowledge. Biological Conservation 191:139-149.

Seibold S, Bässler C, Brandl R, Fahrig L, Förster B, Heurich M, Hothorn T, Scheipl F, Thorn S, Müller J. 2017. An experimental test of the habitat-amount hypothesis for saproxylic beetles in a forested region. Ecology 98:1613-1622.

Soldati F, Barnouin T, Noblecourt T. 2015. Découverte de Bius thoracicus (F., 1792) dans le Vercors (Coleoptera Tenebrionidae). L’Entomologiste 71:193-195.

Stokland JN, Siitonen J, Jonsson BG. 2012. Biodiversity in dead wood. Cambridge University Press, Cambridge.

Sundberg S. 2013. Spore rain in relation to regional sources and beyond. Ecography 36:364-373.

Svensson GP, Sahlin U, Brage B, Larsson MC. 2011. Should I stay or should I go? Modelling dispersal This article is protected by copyright. All rights reserved. 
strategies in saproxylic insects based on pheromone capture and radio telemetry: a case study on the threatened hermit beetle Osmoderma eremita. Biodiversity and Conservation 20:2883-2902.

Sverdrup-Thygeson A, Gustafsson L, Kouki J. 2014. Spatial and temporal scales relevant for conservation of dead-wood associated species: current status and perspectives. Biodiversity and Conservation 23:513-535.

Tischendorf L, Fahrig L. 2000. How should we measure landscape connectivity? Landscape Ecology 15:633-641.

Trakhtenbrot A, Nathan R, Perry G, Richardson DM. 2005. The importance of long-distance dispersal in biodiversity conservation. Diversity and Distributions 11:173-181.

Urcelay C, Robledo G. 2004. Community structure of polypores (Basidiomycota) in Andean alder wood in Argentina: Functional groups among wood-decay fungi? Austral Ecology 29:471-476.

U.S. Forest Service 2015. Forest Service Land Management Planning Handbook, FSH 1909.12 (Amend. No. 1909.12-2015-1); available at www.fs.usda. gov/detail/planningrule/home/?cid=stelprd3828310.

\section{Figure legends}

Figure 1. Evidence for dispersal limitation in insects and fungi at different spatial scales. 'Counts' indicates the number of studies at different scales; note that one study typically included many scales (Appendix S3). Only experimental and genetic studies are included. The diagonal stripes indicate non-European studies. 


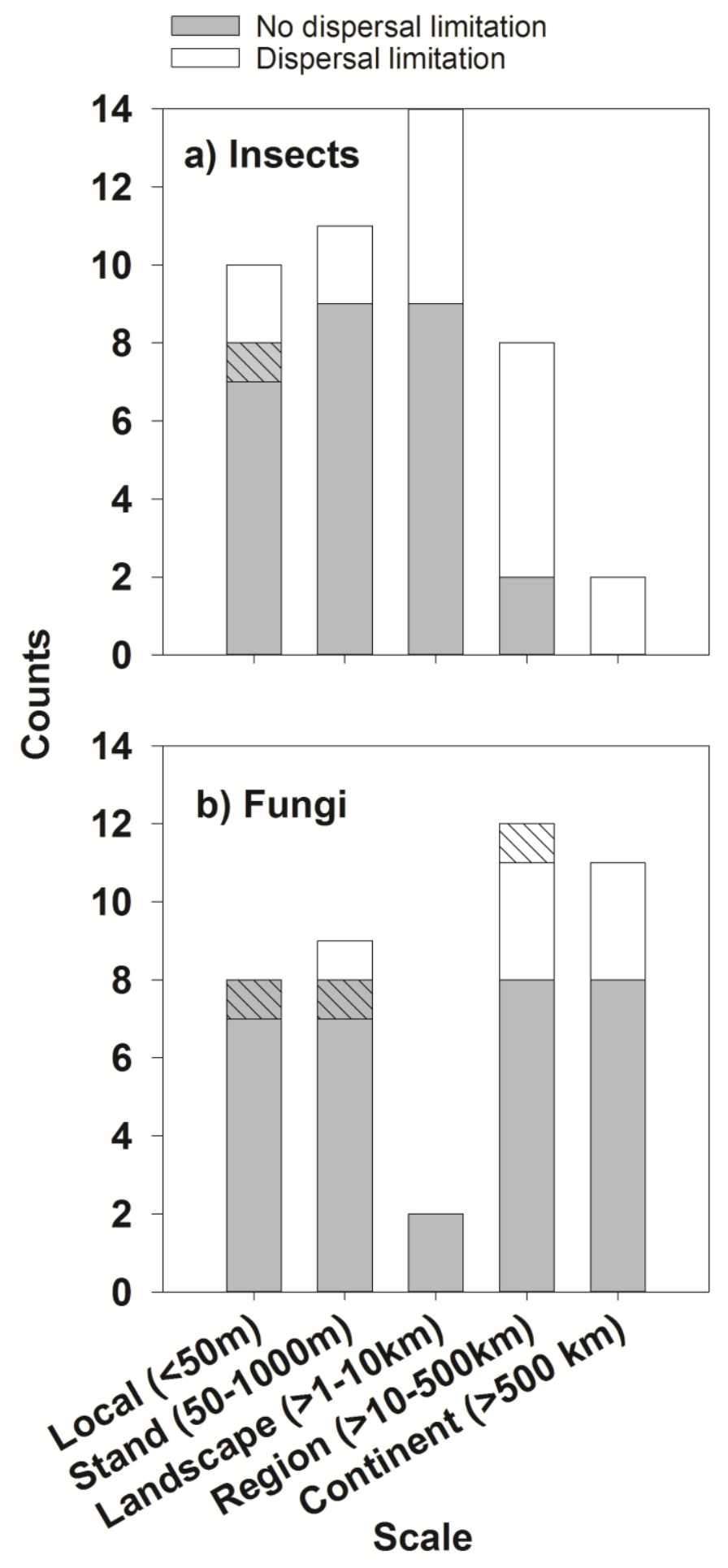

Figure 2. Documented maximum dispersal distances of saproxylic invertebrates in mark-recapture studies ( $n=25$; Appendix S2). 'Counts' indicate the number of studies.

This article is protected by copyright. All rights reserved. 


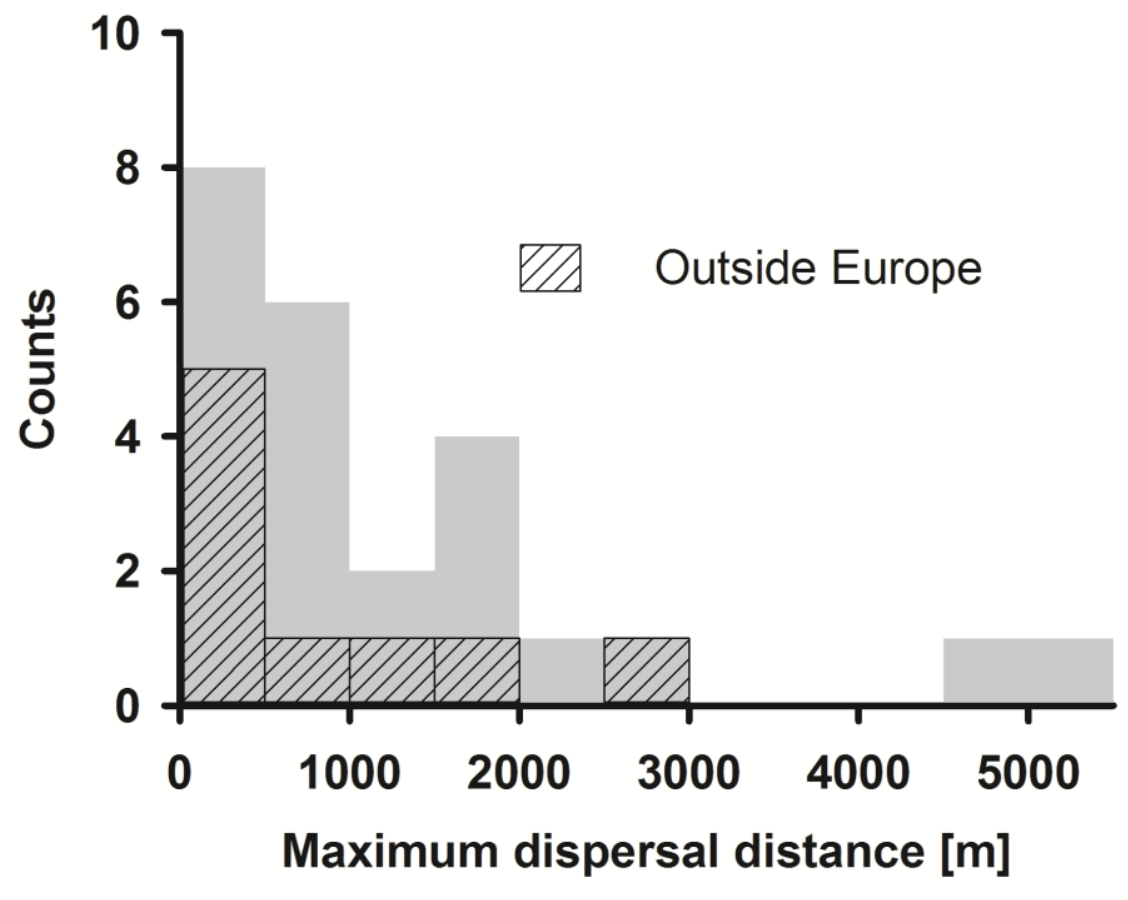


Figure 3. Documented maximum flight distances in studies of the hermit beetle Osmoderma eremita/barnabita with different methods ( $\mathrm{n}=10$ studies; Appendix S2). Direct observation refers to a dispersing individual followed by foot. In the genetic study the distance is average, not maximum.

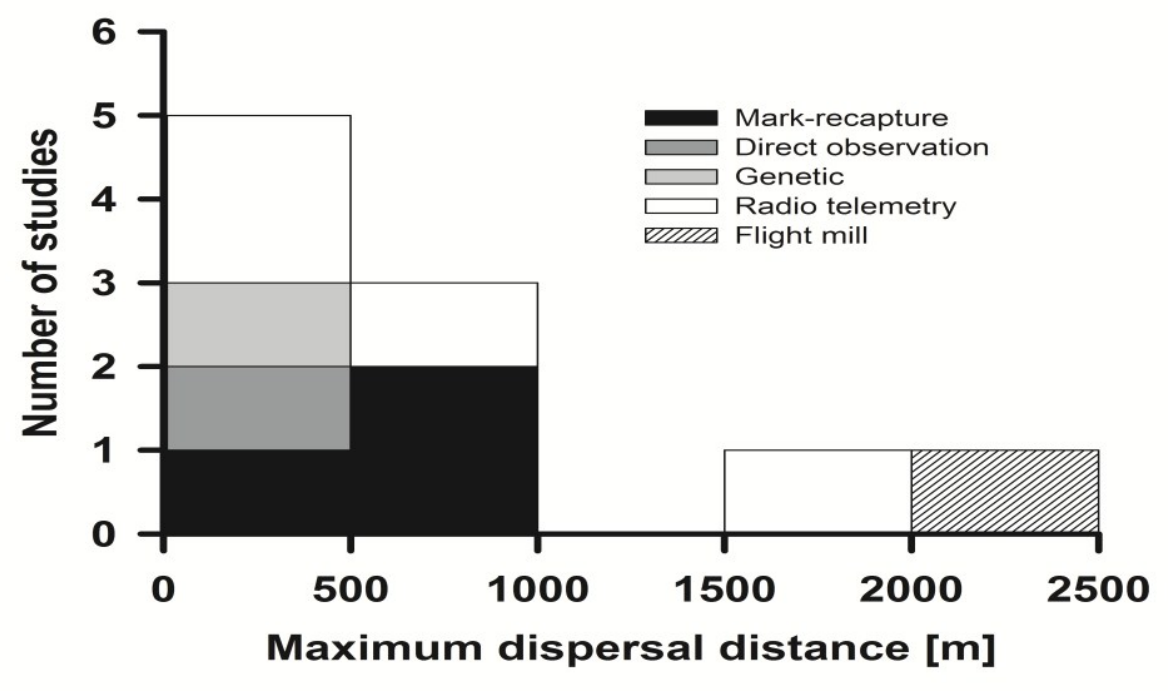

This article is protected by copyright. All rights reserved. 